\title{
Kultury działania i podzielane sposoby organizacji konstrukcji sensu ${ }^{1}$
}

\author{
Książkę tę zrozumie może tylko ten, \\ kto sam już przemyślał myśli w niej wyrażone - albo przynajmniej myśli podobne.
}

(Wittgenstein [1992] 2001: 31)²

\begin{abstract}
Abstrakt
Przedmiotem konceptu kultury działania są ramy myślenia podmiotów i werbalizacji działania. Obserwuje się różnorodność kultur działania w różnych dziedzinach, takich jak: edukacja, praca socjalna, terapia, zarządzanie, aktywność naukowa. Koncept kultury działania może być zdefiniowany jako podzielany i ewoluujący sposób organizacji procesu konstruowania sensu wokół aktywności podmiotów, w które są zaangażowane. Jest on bliski pojęciu episteme w znaczeniu nadanym przez Foucaulta oraz przyzwyczajenia mentalnego (habitude mentale) Panofskiego.
\end{abstract}

Słowa kluczowe: kultura, działanie, myślenie, sens.

\section{Cultures of Action and Shared Ways of Organizing the Construction of Sense}

\begin{abstract}
The object of the culture of action concept is the framework of thinking of entities and verbalization of activity. There has been observed a diversity of cultures of action in various fields, such as education, social work, therapy, management, scientific activity. The culture of action concept can be defined as a shared and evolving way of organizing
\end{abstract}

\footnotetext{
* Conservatoire National des Arts et Métiers w Paryżu, Katedra UNESCO Kształcenia i Praktyk Profesjonalnych/CRF.

${ }^{1}$ Jest to skrócona wersja artykułu pt. Cultures d'action et modes partagés d'organisation des constructions de sens, opublikowanego w roku 2010 w czasopiśmie „Revue d'Anthropologie des Connaissances”, 4 (1), s. 163-194, https://www.cairn.info/revue-anthropologie-des-connaissances-2010-1-page-163.htm; Redakcja „NOWIS” dziękuje Wydawcy za wyrażenie zgody na tłumaczenie i druk w języku polskim.

2 Por. Wittgenstein (2000).
} 
the process of constructing sense around the activity of the involved entities. It is close to the notion of episteme within the meaning given by Foucault and mental habit (habitude mentale) by Panofsky.

Keywords: culture, action, mind, sense.

Osoby, które w swojej pracy naukowej bądź dydaktycznej zajmują się analizą aktywności profesjonalnych, a szerzej tym, co można określić jako 'myślenie o działaniu' bądź 'działalność intelektualna', z pewnością zgodzą się z trzema następującymi stwierdzeniami, dotyczącymi:

- silnie naznaczonej w pewnych okolicznościach obecności niezmiennych elementów, obserwowanych pewnych regularności w dyskursie na temat koncepcji i prowadzenia działania profesjonalnego oraz zarządzania nim czy posługiwania się w różnych kontekstach terminologią działania racjonalnego, formułowaniem celów ewaluacji. Te regularności dyskursu są 'oczywiste' dla naszego myślenia;

- powtarzalności proponowanych formalnych modeli działania, które oprócz zmian w samej formie opierają się na bardzo podobnych odniesieniach, jak na przykład: prymacie dawanym aktywności podmiotu, wyrażanym w tym, co określa się jako wymóg subiektywności, obecnym w wielu modelach organizacji pracy i produkcji (uczestnictwo/partycypacja pracowników w przebiegu procesów produkcji), jak też w modelach kształcenia (głównym punktem odniesienia staje się podmiot uczący się);

- częstego mylenia, tak w analizach, jak i badaniach, aktywności z wypowiedziami na temat aktywności. Wiele analiz i badań odnoszących się do aktywności profesjonalnych dotyka jedynie dyskursu na ich temat. A to, co przedstawia się jako 'praktyki' stanowi jedynie wypowiedzi podmiotów na temat ich własnych aktywności, które ograniczają się jedynie do powtórzenia 'dominujących' i powszechnych kategorii. W efekcie analizowanie tego dyskursu nie prowadzi do analizy działalności, lecz jedynie do nadania pewnej formy kulturom, w których aktorzy myślq i realizują działania.

Do prześledzenia powstawania tych zjawisk wydaje nam się niezbędne odniesienie do kategorii: kultury działania profesjonalnego obecnej w różnych obszarach aktywności. Można mówić więc o kulturze: kształcenia, działania społecznego, działania terapeutycznego, zarządzania czy też działalności kulturalnej. Można przypuszczać, że w pojawianiu się i rozwoju tych kultur działania profesjonalnego mamy do czynienia z 'przyzwyczajeniami mentalnymi'/'bruzdami rozumu'3, które jawią się jako oczywiste schematy nabyte i podzielane w danych okolicznościach przez określony zespół osób, które podobne są, mutatis mutandis, do mechanizmów

${ }^{3}$ Bliżej na ten temat: Barbier (2016). 
występujących w wielkich skupiskach ludzkich. Można więc mówić ogólniej o kulturach działania, które wstępnie zdefiniujmy jako formy/sposoby działania w czynie ${ }^{4}$, wspólne danej grupie osób w myśleniu o działaniu, w projektowaniu i prowadzeniu działania, a ogólniej w konstruowaniu sensu wokół nich i nadawaniu im znaczenia.

Termin działanie nie oznacza tu jedynie (w każdym razie nie wyłącznie) bezpośredniej transformacji świata, lecz użyty jest w znaczeniu bardziej ogólnym jako ogół czynności posiadających jedność sensu i/lub znaczenia dla podmiotu lub podmiotów zaangażowanych $w$ nie $w$ ramach interakcji z innymi podmiotami.

Ta wstępna definicja pozwoli nam prześledzić niektóre postawy intelektualne zbliżone do niniejszego projektu oraz ukierunkować go filozoficznie, w sensie powszechnym tego słowa, dla autora jest to raczej ukierunkowanie wykraczające poza ujęcie epistemologiczne, nazwałbym je antropologią form i sposobów myślenia o działaniu.

\section{Porzucanie przyzwyczajeń mentalnych i ram myślenia}

Jeśliby mierzyć przedsięwzięcie intelektualne możliwością poszerzania własnego zasięgu myślenia, to z pewnością dzieło François Julliena ([2000] 2005) jest dla jego czytelników bardzo szczególne, gdyż pozwala nabrać dystansu wobec własnych ram myślenia. Zgodnie z pozycją filozofa, a ściślej intelektualisty, autor ten już na wstępie określa w swoich tekstach i wykładach intencję zdystansowania się do własnego myślenia i przyjęcie za przedmiot myślenia warunki czysto intelektualne, a więc jego własne ramy myślenia, które zgodnie z jego hipotezą są wspólne całej kulturze europejskiej, mającej swoje korzenie w kulturze greckiej, z którą rzeczywiście identyfikuje się myśl zachodnia.

Aby osiągnąć to oddalenie, autor, odnosząc się do przykładu Chin, proponuje sobie i swoim czytelnikom badanie myśli zachodniej 'z zewnątrz', z pozycji 'radykalnej zewnętrzności' historii i języka, poprzez pewne odejście, krok w bok, 'drogę na skróty'. W mniejszym stopniu interesują go idee, pojęcia, a bardziej to, co ukryte, nabyte i podzielane, co wyraża myślenie oczywistościami, z pomocą tego, co 'nie do pomyślenia', co stanowi 'bazę porozumienia', często ukrytą w języku; jej trwałość jest tym większa, gdyż nie wymaga żadnego komentarza w jego obrębie. Celem finalnym jest ujawnienie lub ukazanie tego, co „ukryte w naszych sposobach myślenia” (Jullien [2000] 2005: 11), „wyborów ukrytych w naszym umyśle lub tych, o których zapomnieliśmy" (tamże) ${ }^{5}$.

Przedsięwzięcie to jest wyjątkowe z racji swojego zasięgu, głębi, finezji i jasności wypowiedzi, bliskie jest drogom intelektualnym, którymi podążali na przykład

\footnotetext{
${ }^{4}$ Tamże: 114.

${ }^{5}$ Por. także Jullien (2006).
} 
Erwin Panofsky i Michel Foucault. Z pewnością inspirowały ich inne źródła, jednakże widoczna jest homologia przedmiotu myślenia, a także ogromna erudycja filozoficznych rozważań. Wprawdzie Panofsky ([1951] 1967) jest specjalistą w zakresie sztuki, ale podejmując refleksję na jej temat, zastanawia się nad aktywnością ludzką. To zainteresowanie jawi się bardzo wyraźnie w jego stymulującej broszurze zatytułowanej Architektura gotycka i scholastyka. Świetnie znając tak zalety, jak i zagrożenia swego przedsięwzięcia ustanowienia „wewnętrznych analogii między zjawiskami tak z pozoru odmiennymi, jak sztuka, literatura, filozofia, wydarzenia społeczne i polityczne, ruchy religijne etc." (tamże: 69), podejmuje jednak ryzyko scharakteryzowania „nowego stylu myślenia i nowego stylu architektonicznego”, który pojawia się w wieku XII i trwa przynajmniej150 lat, biorąc swój początek na obszarze „otaczającym Paryż w promieniu stu pięćdziesięciu kilometrów” (tamże: 72). Ponadto wskazuje na „nowy sposób percepcji lub raczej ujęcia w zależności od aktu percepcji” (tamże: 79), wypracowany przez 'wielu mistrzów różnych narodowości', którzy „wpływali także na zmiany w sztuce”6. Za cel szczególny obiera ukazanie 'nawyku mentalnego'7, sprowadzając ten zużyty schemat w sensie scholastycznym do bardziej precyzyjnej 'zasady principium importans ordinem ad actum', 'która rządzi czynem'8 (tamże: 83), bowiem przyzwyczajenia/nawyki mentalne są 'w użyciu we wszystkich cywilizacjach'. Te przyzwyczajenia/nawyki są najczęściej nieświadome i zawsze 'generują' praktyki, co wyjaśnia zainteresowanie nimi Pierra Bourdieu i wysiłek, jaki włożył w sformułowanie pojęcia habitusu9.

W pracach Michela Foucault: Słowa i rzeczy ([1966] 2004) ${ }^{10}$ oraz Archeologia wiedzy ([1969] 2004) mamy do czynienia z odmiennym i specyficznym materiałem, gdyż autor skupia się na aktywności wytwarzania i komunikacji wiedzy. Jednakże intencja jest analogiczna, a mianowicie wskazanie na powiązanie między sprzyjającymi okolicznościami a kulturą określonych sposobów myślenia oraz wyodrębnieniem $\mathrm{w}$ nich pojawiających się transformacji. Robi to, posługując się pojęciem episteme, które rozumie jako - jak pisze -

ogół relacji, które mogą łączyć w jakiejś epoce praktyki dyskursywne umożliwiające pojawienie się figur epistemologicznych, nauk i ewentualnie systemów sformalizowanych, trybu, według którego (...) dokonują się przejścia (...) (Foucault [1969] 2004: 250).

Episteme - pisze Foucault (1968) - nie jest jedną z wielkich podstawowych teorii sous-jacente, jest przestrzenią dyspersji, otwartym polem i z pewnością w sposób nieopisany opisuje relacje, episteme nie jest cząst-

\footnotetext{
${ }^{6}$ Wyrażenie pochodzi prawdopodobnie od samego opata Sugera.

${ }^{7}$ Podkreślenie pochodzi od autora.

${ }^{8} \mathrm{~W}$ tym przypadku akt myślenia.

9 Bourdieu w posłowiu do tej książki Pannofskiego ([1951] 1967: 148) mówi o transformacjach zbiorowego dziedzictwa zachodzących w nieświadomości indywidualnej i zespołowej.

10 Por. Foucault (2006).
} 
ką historii wspólnej wszystkim naukom, jest jednoczesną grą specyficznych remanencji/skutków/przejawów/, episteme nie jest ogólnym stadium rozumu, to złożony stosunek sukcesywnych odchyleń (tamże: 676-677) ${ }^{11}$.

Inne przedsięwzięcia podobnej natury mają różny stopień sformalizowania, można tu przypomnieć na przykład pracę Maxa Webera ([1904-1905] 1964]) Etyka protestancka a duch kapitalizmu i jego koncept parenté (Wahlverwandschaft), pokrewieństwa wyboru, a także, choć w nieco innym rejestrze sytuującą się, pracę Thomasa Kuhna ([1962] 1991) Struktura rewolucji naukowych, w której autor rozwija pojęcie paradygmatu. Również nową i oryginalną pracę Douglasa Hofstadtera ([1979] 1987) na temat pokrewieństwa, podobieństw między różnymi aktywnościami ludzkimi w różnych kontekstach, w której autor bada sposoby wzajemnych odniesień i zależności między różnymi poziomami tego, co nazywa niespotykanymi pętlami (boucles étranges), obecnymi zarówno w dziełach muzyków, rysowników, jak i matematyków.

\section{Podejście do kultur działania}

Wprawdzie zbliżenie się do analizowania kultur działania nie wymaga przyjęcia odmiennej postawy intelektualnej, niż te wcześniej wspomniane, jednak to odejście od nich pozwala zastanowić się nad czterema ważnymi kwestiami, które obejmują:

- uznanie, że koncepty i pojęcia stosowane w obrębie działania nie są narzędziami interpretacji, lecz jedynie stanowią materiał do interpretacji. Oznacza to, że nie należy traktować jako wyjaśnienie tego, co wymaga wyjaśnienia. Te koncepty i pojęcia są zazwyczaj wzajemnie powiązane; aby je wskazać i ujawnić ich spójność, odnosząc się do terminologii Paula Ricoeura i L. Quéra, stosujemy również w innych pracach (Barbier $2000 \mathrm{a}, \mathrm{b})^{12}$ pojęcie semantyki lub słownictwa działania ${ }^{13}$;

- kontekstualizację tych pojęć i konceptów, a więc zastanowienie się nie tylko nad ich treścią, ale także nad kontekstami, w jakich są stosowane oraz spełnianymi w nich funkcjami;

- zainteresowanie nie tylko dyskursem i werbalizacją, lecz także mechanizmami mentalnymi podmiotów. Panofsky ([1951] 1967) posługuje się bardzo trafnym sformułowaniem: „Kiedy staramy się opracować nawyki mentalne wytworzone przez pierwotną i klasyczną scholastykę, która wpłynęła

\footnotetext{
${ }^{11}$ Cyt. za: Foucault (1977: 231).

12 Por. tłum. na język polski: Barbier (2006: 255-268), rozdz. 9. Semantyka działania i semantyka pojmowalności działań.

${ }^{13}$ W odróżnieniu od słownictwa czy semantyki pojmowalności działania. Por. Barbier (2016: 205, 208).
} 
na klasyczną gotycką architekturę, należy wziąć w nawias treść pojęciową doktryny i skoncentrować uwagę, na modus operandi" (tamże: 89);

- uprzywilejowanie w badaniu momentów transformacji tych kultur działania lub styków z innymi kulturami, a więc przejść, często gwałtownych, od jednej kultury do drugiej, zależności i nacisków pojawiających się między nimi, zjawisk akulturacji etc.

Nie chodzi tu wyłącznie o stanowisko epistemologiczne. Jeśliby zdefiniować epistemologię jako poznanie aktu poznania, to oczywiście nie moglibyśmy zawęzić przedmiotu badania jedynie do kultur działania, gdyż tworzenie wiedzy stanowi tylko jedno z możliwych działań spośród innych. Wszystkie te działania bez względu na ich specyficzną orientację przebiegają wraz z innymi lub są składowymi aktywności konstruowania ich własnego sensu; a interesują nas - mimo że są trudno uchwytne jako przedmiot badań - przede wszystkim sposoby, według których przebiegają te aktywności konstrukcji sensu, w wymiarze podzielanym przez daną zbiorowość ludzką. Kultury działania zawierają zespół form myślenia towarzyszących działaniom i odnoszących się do działania, będzie to z pewnością indywidualna wiedza własna, lecz także odniesienia do działania, reprezentacje otoczenia, reprezentacje siebie, myślenie o organizacji działania i perspektywach. Mamy tu do czynienia z antropologia form myślenia odnoszącego się do działań, w której składniki semantyczne odgrywają istotną rolę.

Podobnie jak analiza własnych działań podmiotów uważana jest dziś za najlepszy sposób prowadzący do konstruowania sensu wokół własnej aktywności, tak też przyjęcie za przedmiot badania kultur działania jest aktualnie istotnym wyzwaniem, gdyż wymaga ich poznania i choćby częściowego - jak to formułuje François Jullien ([1992] 2003) ${ }^{14}$ - „zatrzymania się w tej drodze” (déjouer) w celu 'wykorzystania' tego 'kroku w bok'. Nie ulega wątpliwości, iż takie stanowisko określa także część pewnej kultury działania.

\section{Kultura działania i pojęcia z nią związane}

W nawiązaniu do 'przyzwyczajeń mentalnych' czytelnika może warto teraz, dla lepszego zrozumienia dalszej części, doprecyzować proponowany koncept kultury działania i ewentualnie przy tej okazji kategorie pojęciowe z nim związane ${ }^{15}$.

Kulturą działania nazywać będziemy ewoluujący i podzielany przez wiele podmiotów sposób organizacji konstrukcji sensu wokół aktywności, w jakie są zaangażowane. Te konstrukcje mogą sprzyjać komunikacji w ramach interakcji z drugim.

\footnotetext{
${ }^{14}$ Por. wydanie polskie pracy tego autora: Jullien (2006).

15 Niniejszy tekst wpisuje się w analogiczne prace autora, m.in. Barbier (2016), dotyczące opracowania definicji pojęć związanych z problematyką konstruowania aktywności i konstytuowania podmiotów w tychże aktywnościach [przyp. tłum.].
} 


\section{Sposób organizacji konstrukcji sensu}

Sposób organizacji konstrukcji sensu można zdefiniować jako wnioskowanie na podstawie niezmiennych lub regularności obserwowalnych $w$ organizacjach aktywności-w-czynie. Zatem jest to wnioskowanie tak jak we wszystkich konceptach pojmowalności (fr. intelligibilite) wytworów w naukach społecznych, a szerzej w nauce, koncept kultury działania jest konstruktem, który relacjonuje to, co obserwowalne. W środowiskach naukowych częsta jest tendencja do przyswajania/naturalizowania pojęć, do postrzegania rzeczywistości 'zewnętrznej' przez ich pryzmat, jako instrumentu mentalnego i dyskursywnego służącego do zrelacjonowania tego, co obserwowalne. W przypadku konceptu kultury taka praktyka może skutkować oczywiście szczególnie niekorzystnymi konsekwencjami.

Sposób organizacji konstrukcji sensu jest budowany na podstawie:

- obserwowalnych regularności: różnorodność konstruktów mentalnych stanowi tu w mniejszym stopniu punkt wyjścia dla formułowania podejścia do kultur działania, w większym zaś są nimi obserwowalne niezmienne, które można wyróżnić w tych konstruktach;

- organizacji aktywności-w-czynie: Jullien mówi o bruzdach rozumu (plis de raison), Panofsky o przyzwyczajeniu/nawyku mentalnym i fakt, że chodzi tu o aktywności mentalne nie podważa zainteresowania modus operandi, gdyż nie angażuje on świadomości podmiotu, choć oczywiście nie wyklucza jej. Przyzwyczajenia/nawyki mentalne często są nieuświadomione, zapomniane lub ukryte na poziomie podmiotu indywidualnego bądź grupy przynależności (jak w przypadku zapominania o pochodzeniu konstrukcji słów/źródłosłowia). Zdaniem Julliena, kultury działania wywodzą się w większości z tego, co 'niepomyślane', z procesów nieuświadomionych lub ukrytych, tym bardziej interesujących, gdy chodzi o to, nad czym się nie zastanawiamy w procesie myślenia (impensés de pensée).

\section{Podzielanie przez wielu}

Podzielany nie oznacza kolektywny/zbiorowy. Precyzja jest niezmiernie ważna w dobie obecnej, gdy kierujący organizmami społecznymi wywierają silny nacisk na swoich członków, aby wszyscy konstruowali ten sam sens lub nadawali to samo znaczenie działaniom zbiorowym, a także temu, co każdy z nich wnosi do całości (szczególnie dzięki działaniom koordynującym), a wszystko to w tym celu, aby powstały w efekcie zbiorowe reprezentacje tożsamościowe. Prowadzone badania oraz obserwacje pozwalają na wyodrębnienie podobnych kultur działania podmiotów bardzo rozproszonych pomimo przynależności do tej samej zbiorowości ludzkiej: a więc „wielu mistrzów różnych nacji”, jak mówił Suger. 
Wielka spójność, jaką widzimy w przestrzeni i czasie, tak w myśli chińskiej, jak i europejskiej jest tego dobitnym przykładem. 'Wielu' może być tutaj rozumiane, jako wielkie zespoły ludzkie, ale także jako małe grupy, i niekoniecznie musi odnosić się do działań wspólnych. We wszystkich przypadkach mamy do czynienia $\mathrm{z}$ procesem podzielanym, lecz nie jest to proces wspólny czy zbiorowy. Analiza aktywności odwołuje się dziś często do pojęcia reprezentacji podzielanych ${ }^{16}$.

\section{Podmioty - wnioskowanie o nich}

Nie ma kultury, której nośnikiem nie byłyby podmioty ludzkie. Dlatego ważne jest rozróżnienie, zgodnie z dawnym nazewnictwem, 'wytworów/dzieł' aktywności ludzkiej, które uważa się za 'manifestacje/przejawy' kultury (podczas gdy są one jedynie wnioskowaniem wytworzonym na ich podstawie) i tego, co możemy na ich podstawie wnioskować na temat jednostek ludzkich będących ich twórcami, a co wywodzi się z samej kultury. Uważamy ten punkt za ważny, gdyż w literaturze o intencji naukowej w większości definicji pojęcia kultury te dwa aspekty mieszają się.

Przykładem może być pierwsza definicja 'etnologiczna' kultury, zaproponowana przez brytyjskiego antropologa Edwarda B. Tylora (1871), powiązana z definicją cywilizacji: „Kultura, czyli cywilizacja, w szerokim etnograficznym sensie, jest złożoną całością, która obejmuje wiedzę, wierzenia, sztukę, moralność, prawo, obyczaje i inne zdolności i nawyki zdobyte przez człowieka jako członka społeczeństwa" (tamże: I) ${ }^{17}$.

Taki sens odnajdujemy także w definicji proponowanej przez Clauda Lévi-Straussa (1962): „Kultura może być uważana za zespół symbolicznych reguł, wśród których na pierwszym planie sytuują się język, reguły matrymonialne, stosunki ekonomiczne, sztuka, nauka, religia” (tamże: XIX) ${ }^{18}$. Bardziej precyzyjny jest tu Abraham Moles (1967), który pisze: „ślad pozostawiony przez to sztuczne środowisko w umyśle każdego człowieka jest tym, co nazywamy kulturą” (tamże: 19). Moles definiuje to pojęcie jako:

intelektualny aspekt sztucznego środowiska, tworzonego przez człowieka w trakcie jego życia społecznego. Jest to abstrakcyjny element jego Umwelt w znaczeniu nadanym przez Uexkülla (...). Termin kultura obejmuje ogół aspektów intelektualnych, obecnych w jednym lub wielu umysłach i posiada pewną stabilną, zmaterializowanq̨ ${ }^{19}$ postać $\mathrm{w}$ formie zbiorów bibliotek, dzieł i języków (tamże: 67-68).

\footnotetext{
16 W dziedzinie zarządzania Thevenet (1983) mówi o 'oczywistościach podzielanych w przedsiębiorstwie'.

17 Cyt. za: Szacki (2002: 306).

18 Por. Lévi-Strauss (1970: 375). Cyt. za: Szacki (2002: 678).

19 Podkreślenie pochodzi od autora.
} 
Zgodnie z naszym przypuszczeniem względna niedookreśloność ${ }^{20}$ charakterystyczna dla definicji kultur jest związana z faktem, iż dzieła są przypuszczalnie nośnikiem 'śladu' kultur oraz ich 'przejawami', co pozwala zrozumieć rozszerzenia zastosowań tego terminu. W rzeczywistości dzieła pozwalają wnioskować o procesach przebiegających u ludzi, nie mogą ich zastępować. Termin cywilizacje wydaje się być o wiele bardziej stosowny do określenia (z punktu widzenia obserwatora) znaczących zespołów aktywności ludzkich, instrumentów i wytworów.

\section{Sposób ewoluujący}

Powiedzenie o kulturze, że jest nierozerwalnie związana z podmiotami ludzkimi i ich stosunkami z otoczeniem, prowadzi oczywiście nieuchronnie do pytania o jej konstrukcję i ewolucję. Kultury, nawet jeśli stanowią prawdopodobnie przejściowe lub nawet bardziej trwałe stabilizacje tego procesu, są wytworem aktywności i przyczyniają się do ich wytworzenia. Edgar Morin (2001: 195) często przytacza w swoich pracach prostą definicję kultury będącej 'tym, co nie jest dziedziczne'. Dla Ralpha Lintona (1988) „kultura jest konfiguracją wyuczonych zachowań i ich rezultatów, których elementy składowe są podzielane i przekazywane przez członków danego społeczeństwa” (tamże: 33-34)21. Nawet jeśli słowo „transmisja” nie zawsze jest właściwe, to kultura i nauczanie sq ściśle powiq̨zane, jeśli nauczanie rozumieć będziemy jako transformację pewnej stałej sekwencji aktywności. Nie jest dziełem przypadku, iż termin „kultura” pochodzi od łacińskiego słowa colere, co oznacza rozwijać, i często związany jest z terminem edukacja, w szerokim sensie tego słowa 22 .

\section{Organizacja konstrukcji sensu wokół aktywności, w jakie (podmioty) są zaangażowane}

Chodzi tu oczywiście o najważniejszy aspekt naszej definicji. Jeśli sens może być zdefiniowany jako skojarzenie dokonywane przez sam podmiot między reprezentacjami pochodzącymi z bieżącej aktywności i innymi reprezentacjami, które pojawiły się w trakcie jego drogi życiowej, wówczas zobaczymy, że jednostki ludzkie w trakcie swojej aktywności stale dokonują tego rodzaju konstrukcji, a te odnoszą się zarówno do otoczenia ich aktywności, ich organizacji i przebiegu, jak

\footnotetext{
${ }^{20}$ Malinowski ([1944] 1970: 39) podkreśla, że instytucja jest „realną jednostką w analizie kultury” i że „żaden element, cecha, zwyczaj czy idea nie może być określany inaczej jak przez rozpatrzenie go w powiązaniu z jego istotnym i realnym środowiskiem instytucjonalnym”, cyt. za: Malinowski ([1944] 1958): 42), http://docplayer.pl/8591113-Bronislawa-malinowskiego funkcjonalna-teoria-kultury.html [dostęp: 1.09.2016].

${ }^{21}$ Cyt. za: Linton (2000: 47-48).

22 Przestudiujemy ten punkt w sposób bardziej pogłębiony przy okazji omawiania konstruowania kultur działania.
} 
i do nich samych, jako podmiotów działających, i do innych podmiotów, z którymi pozostają w interakcji. Jeremy Bruner (1996) w swojej koncepcji psychologii kulturowej przypisuje największe znaczenie konstrukcjom sensu: „indywidualna ekspresja [kultury], jak pisze, ujawnia się $w$ wytwarzaniu znaczeń, przypisywaniu znaczeń rzeczom w konkretnych sytuacjach w rozmaitym otoczeniu"23.

Tworzenie znaczeń implikuje sytuowanie spotkań ze światem w odpowiednich kontekstach kulturowych, w celu zrozumienia 'o co chodzi'. Nawet jeśli znaczenia te sytuują się 'w umyśle', to pochodzą i czerpią znaczenie w kulturze, w jakiej zostały wytworzone. To, iż znaczenia są kulturowo usytuowane pozwala na ich negocjowanie i w efekcie na ich komunikowanie.

Tak więc wiedza i komunikacja są z natury wzajemnie zależne, a nawet wirtualnie nierozerwalne. Nawet wówczas, gdy wydaje się, że jednostka sama poszukuje sensu, to nie zdoła tego zrobić bez pomocy systemów symbolicznych właściwych kulturze. To kultura daje nam komunikowalne narzędzia, pozwalające na organizację i zrozumienie światów, które nas otaczają (tamże: 17).

Konstrukcje sensu są:

- konstrukcjami mentalnymi, co wyjaśnia ich wyjątkową mobilność i niedostępność, a także ich związek z tym, co zwyczajowo nazywamy mentalnością będącą m.in. przedmiotem zainteresowania historyków ${ }^{24}$ ze Szkoły „Annales" czy etnologów, jak Lucien Levy-Bruhl (1910; [1922] 1960)25;

- nieodłącznie związane z konstrukcjami dyskursywnymi, obecnymi w interakcjach z innym, są wspierane lub przekształcane przez te konstrukcje; jednakże nie należy ich mylić z komunikatami, które prowadzq do konstruowania sensu, gdyż te sq częściq kultury w znaczeniu odrębnej dziedziny aktywności społecznej, o której powiemy w dalszej części artykułu;

- nie są jedynie konstrukcjami mentalnymi, mają bowiem ścisły związek z afektami i dyspozycjami/skłonnościami podmiotu do angażowania się w aktywności (tak jak w przypadku habitusu u Pierra Bourdieu). Z tego też punktu widzenia łatwiej jest zrozumieć miejsce, jakie zajmuje w literaturze naukowej na temat kultury afirmacja 'sił dynamicznych' podmiotu i jej związku z 'postawami'.

Formułujemy przypuszczenie, że kultury działania mogą być zdefiniowane, jako sposoby organizujące aktywności konstruowania sensu. Ta właściwość jest szczególnie widoczna w zjawisku akulturacji, opisywanym przez Mellvina Herskovitsa ([1948] 1952), jako procesy re-interpretacji, to znaczy procesy, dzięki którym dawne znaczenia przypisywane są nowym elementom bądź też, dzięki którym nowe wartości wpływają na zmianę znaczenia kulturowego starych form.

\footnotetext{
${ }^{23}$ Cyt. za: Bruner (2006: 16).

${ }^{24}$ Chodzi o badania nad historią mentalności.

25 Por. Levy-Bruhl ([1918] 1992).
} 


\section{Komunikacja z drugim w procesie konstrukcji sensu}

Te konstrukcje mogą prowadzić do komunikacji w ramach interakcji z innymi podmiotami lub grupami podmiotów. Denys Cuche ([1996] 1998) zauważa, że „słowo 'kultura' nie ma odpowiednika w większości języków mówionych społeczności zazwyczaj badanych przez etnologów” i komentuje to następująco: „nie oznacza to oczywiście (tym bardziej, iż nie jest to opinia powszechnie podzielana!), że społeczeństwa te nie posiadają kultury, lecz że nie zastanawiają się nad tym, czy ją posiadają czy też nie, i tym bardziej nie definiują własnej kultury" (tamże: 7).

Formułujemy hipotezę, że termin „kultura” w najczęstszych zastosowaniach społecznych (np. w dziedzinie kultury) pojawia się w sytuacjach interakcji, przy okazji ujawniania się specyficznych form komunikacji z drugim i różnych kanałów ekspresji oraz w procesie konstrukcji sensu tworzonego przez podmioty lub grupy podmiotów. Wówczas to pojawiają się aktywności lub sektory aktywności posiadających społeczne znaczenie oraz odrębny status. W tradycyjnym ujęciu będą to sektory: sztuki, literatury i nauki; w bardziej współczesnym zaś, to: produkowanie, upowszechnianie i konsumpcja produktów/wytworów umysłu.

\section{Funkcjonowanie i konstruowanie kultur działania}

Bez względu na wielkość i zasięg kultur działania można wyróżnić kilka ich podstawowych cech. Funkcjonują one jako okresowe lub trwałe i ustabilizowane związki i połączenia.

(...) zdefiniowalibyśmy kulturę, jak pisze Moles (1967), jako sumę prawdopodobnych połączeń wszelkich porządków między elementami poznania i wyróżnilibyśmy pełny zakres kultur, a mianowicie takie, w których relacje między poszczególnymi elementami poznania są częste i silne (tamże: 36).

\section{Kultury działania jako okresowe lub trwałe związki oraz połączenia}

Foucault często stosuje pojęcie relacji. Takie ujęcie zbliża pojęcie kultury działania do innych pojęć stosowanych w naukach społecznych, na przykład do pojęcia toposu stosowanego przez Oswalda Ducrota ${ }^{26}$ i definiowanego jako podstawowa zasada w argumentacji stosowanej w dyskursie, będącej „gwarantem umożliwiającym przejście od argumentu A do konkluzji C" (Anscombre 1995: 85). A także do pojęcia schematu mentalnego, stosowanego w psychologii, lub jeszcze pojęcia schème stosowanego w socjologii rozumiejącej Alfreda Schütza ([1932] 1974: 109).

26 Por. Ducrot (1989). 
Kultury działania mogą być rozumiane jako topoï, schematy mentalne, schematy doświadczenia czy typy. Widać także, że pojęcia: „połączenia” i „relacja” znajdują się w centrum większości koncepcji konstruowanych w celu analizy aktywności podmiotów, jak na przykład: habitus, schème, pattern variables, scenariusz (script), montaż etc. Pojęcia kultury, przyzwyczajenia mentalnego czy schematu myślowego, toposu kładą nacisk na aspekt mentalny tych połączeń; nie oznacza to jednak, że odrzuca się w nich możliwość zachodzenia asocjacji z innymi elementami. Rzeczywiście takie połączenia są możliwe, chociażby do objaśnienia, co dzieje się wówczas, gdy mamy do czynienia ze związkiem: wrażenie - percepcja.

Aby dotrzeć do tych związków, które mogą przybierać formę kompletnych systemów relacji, Moles (1967) stosuje analizę treści dyskursu, jest to oczywiście bardzo ważna droga, lecz niebezpośrednia. Także zalecenie Foucaulta ([1969] 2004), aby analizować formy dyskursywne nie jest znacząco odmienną propozycją; co prawda autor przede wszystkim interesuje się wytwarzaniem i upowszechnianiem wiedzy, które w szerokim zakresie są dyskursywne.

W wypadku, gdy - jak pisze - uda się ustalić w jakiejś grupie wypowiedzi podobny system rozproszenia, $\mathrm{w}$ wypadku, gdy zdołamy określić jakąś regularność w obrębie przedmiotów, sposobów wypowiadania, pojęć i wyborów tematycznych (porządek, korelacje, pozycje, funkcjonowanie, transformacje), powiemy zazwyczaj, że mamy do czynienia z pewną formacją dyskursywną. Będziemy nazywać regułami formacyjnymi uwarunkowania, jakim podlegają elementy tego systemu (przedmioty, modalności wypowiedzi, pojęcia, wybory tematyczne) (tamże: 53)27.

Analiza dyskursu, która w odróżnieniu od analizy treści skupia się na stosunku, jaki podmioty utrzymują z własnym dyskursem, jest $\mathrm{z}$ pewnością interesującą propozycją w tym podejściu.

\section{'Oczywistość' związków i połączeń konstruowania kultur działania}

Te związki i połączenia są uznawane przez podmioty jako „prawdziwe/pewne”. To bardzo istotny punkt analizy. François Jullien odwołuje się często do pojęcia 'oczywistości' (évidence). John Dewey ([1938] 1993) do 'ustalonych przyporządkowań' (assertions garanties), czyniąc je ważnym aspektem badań (enquêtes) prowadzonych przez podmioty $\mathrm{w}$ danej sytuacji, umożliwiającym im podejmowanie działania. Ducrot mówi o toposach (topoi), którymi są „wierzenia przedstawiane jako wspólne dla pewnej społeczności, do której przynajmniej przynależy mówiący i jego rozmówca; przypuszczalnie podzielali oni tę wiarę przed pojawieniem się dyskursu, w którym jest omawiana" (Anscombre 1995: 86). Dla Schütza ([1932]

${ }^{27}$ Cyt. za: Foucault (1977: 64). 
1974 ) „typy są schematami (schèmes) doświadczenia, funkcjonują jako wynikające same z siebie, jako oczywistości" (tamże: 109). Natomiast dla Khuna ([1962] 1991) 'paradygmaty' aktywności naukowej są regułami przyjętymi i zinterioryzowanymi przez społeczność naukową oraz uznanymi jako 'normy' w danym momencie swojej historii, które określa się w celu wyodrębnienia 'faktów', jakie społeczność naukowa uważa za godne badania ${ }^{28}$.

Natomiast współcześnie, to Gérard Vergnaud, aby podkreślić siłę oddziaływania narzędzi interpretacji, jakimi posługują się podmioty w działaniu, mówi bardzo obrazowo o 'teorematach w czynie'. Przypomnijmy także, że Erving Goffman ([1974] 1991) zwracał uwagę na to, że William James „zamiast zastanawiać się nad naturą rzeczywistości (...) dokonuje odwrócenia fenomenologicznego i zadaje przewrotne pytanie: 'w jakich okolicznościach myślimy, że rzeczy są realne'?" (tamże: 10).

Mamy więc tu do czynienia ze zjawiskiem pewnego przyzwolenia (assentiment) na to, by podjąć analizę w kategoriach przekonań, wiary w solidność, trwałość, a więc oczywistości tych związków i połączeń w ich odpowiedniości do 'rzeczywistości' zewnętrznej, która upoważniałaby do działania. Osąd „prawdziwości” nie musi być uważany za efekt potwierdzenia korespondencji między reprezentacjami czy systemami reprezentacji do przypuszczalnie wyobrażonych „rzeczywistości"... Jak to zauważył Raymond Polin (1977) prawdziwość jakiegoś osądu nie odnosi się do tego osądu, lecz do potwierdzenia jego prawdziwości. Tę samą myśl wypowiada Marcel Duchamp (1975) w sposób bardziej literacki: „Lubię słowo 'wierzyć'. Zazwyczaj, gdy mówimy 'wiem', to nie tyle wiemy, ile wierzymy” (tamże: 185).

Zjawisko assentiment, przyzwolenia/aprobacji, wywodzi się prawdopodobnie z tego, co nazywamy logikami działania, termin ten zamiast określać coś, co byłoby wewnętrzne działaniu, odnosi się do stosunku podmiotów do własnych działań. Logiki działania są czasem definiowane jako zbiór zasad strukturujących mniej lub bardziej świadomie sposób poznawania rzeczywistości, którą badamy, a w konsekwencji sposób oddziaływania ewentualnie na tę rzeczywistość.

\section{Czynniki sprzyjające aktywności konstrukcji sensu}

Te związki i połączenia stanowią dla podmiotów 'możliwe' czynniki sprzyjające aktywności konstrukcji sensu.

Myślenie - pisze Abraham Moles (1967) ${ }^{29}$ - jest procesem aktywnym, odrębnym od kultury, lecz posługuje się nią, aby tworzyć oryginalne konstrukcje. Tworzymy nowe idee, odwołując się do fragmentów

\footnotetext{
${ }^{28}$ Por. m.in. Barnes (1998: 103-107).

${ }^{29} \mathrm{~W}$ języku polskim opublikowana jest praca: Moles (1978).
} 
dawnych idei, słów czy form wcześniej istniejących, atomów poznania, mówiąc ogólnie do kultury oddanej do dyspozycji przez naszą kulturę (...) (tamże: 68). Zaś Kultura (...) to możliwość działania (...) ( tamże: 310).

Aby opisać ten aktywny proces myślenia, Claude Lévi-Strauss (1962) stosuje do analizy myśli mitycznej termin „bricolage”, który pozwala zanalizować procesy konstruowania-rekonstruowania sensu aktywności ${ }^{30}$ oraz uprzednio narzucone jej znaczenia. Chodzi tu o te „elementy składowe mitu - których możliwe kombinacje ogranicza fakt zapożyczenia ich z języka, gdzie posiadają już pewien sens, co ogranicza swobodę manewrowania - elementy gromadzone i wykorzystywane przez bricoleura ${ }^{31}$ mają z góry ograniczone zastosowanie" (tamże: 29) ${ }^{32}$.

Myślenie mityczne także pracuje na zasadzie analogii i przybliżeń, nawet jeśli jego twory - jak w przypadku bricolage'u - sprowadzają się zawsze do nowego ułożenia elementów, których natura nie ulega zmianie w zależności od tego, czy występują w zasobie instrumentalnym czy w układzie ostatecznym (...) (tamże: 31$)^{33}$.

Cytuje on także Franza Boasa (1898: 18): „Można by powiedzieć, że przeznaczeniem mitologicznych wszechświatów jest, zaledwie się uformują, zburzenie, po to, by z ich części rodziły się wszechświaty nowe"34, dodaje także bardzo istotną uwagę: „w toku nieprzerwanej rekonstrukcji z użyciem tych samych materiałów do roli środków powoływane są dawne cele: to, co znaczone zamienia się w to, co znaczące, i na odwrót"35.

Przypomina jednak, że systemy konceptualne, które bada, nie są środkami komunikacji (ani też nie zastępują ich); są to sposoby myślenia, aktywności posiadające uwarunkowania o wiele mniej sztywne.

To, co jest prawdą w odniesieniu do interpretacji i aktywności konstruowania sensu odnosi się także do komunikacji i aktywności dyskursywnych: w pracach na temat znaczenia leksykalnego Olga Galatanu (1999) mówi o 'świecie kwantowym' (monde quantique) znaczenia leksykalnego i stosuje pojęcie 'możliwości argumentacyjnych': znaczenie leksykalne byłoby:

połączeniem stereotypu, skojarzonego w sposób trwały z danym słowem, stanowiącym część jego znaczenia, tradycyjnie określanego jako 'opisowe' i innymi reprezentacjami semantycznymi (czy stereotypami związanymi

\footnotetext{
${ }^{30}$ Tak jak prawdopodobnie w każdej aktywności o algorytmie nakazowym.

${ }^{31}$ Bricolage, bricoleur w literaturze polskiej używane zamiennie z terminem 'majsterkowanie', 'majsterkowicz'. Przyp. tłum.

${ }^{32}$ Cyt. za: Lévi-Strauss (1969: 34).

33 Cyt. za: tamże: 37.

${ }^{34}$ Cyt. za: tamże.

35 Cyt. za: tamże.
} 
z innymi słowami) tworzącymi także argumenty stosowane w dyskursie

i w konstruowanych wypowiedziach na dany temat (tamże: 48).

Ogólnie mówiąc, pojęcie możliwości argumentacyjnych bliskie jest epistemologii kwantowej i może być powiązane z pojęciami konfiguracji i rekonfiguracji, które można zdefiniować jako organizacje czy reorganizacje jednostkowe form regularnych. Prawdopodobnie wszystkie aktywności funkcjonują na zasadzie rekonfiguracji lub rekonstrukcji, a przynajmniej można je tak analizować.

\section{Związki i połączenia konstruowania sensu a reprezentacje przebiegu doświadczeń podmiotu}

W pracy nad konstruowaniem sensu te związki i połączenia pozostają w relacji z reprezentacjami przebiegu doświadczeń podmiotów, które są przez nie 'interpretowane'. Związki te mogą się przy tej okazji same przekształcać. Możemy tu przytoczyć wiele prac na ten temat. Są to prace Alfreda Schütza ([1932] 1974) oraz te, które powstały na ich bazie, a odnoszące się do tematu 'typizacji społecznej'. „Interpretacja, jak pisze, (...) to nic innego jak odesłanie tego, co nieznane do tego, co znane, co rozumiemy w promieniu schematów doświadczenia” (tamże: 112) ${ }^{36}$. Typizacje są określane w zależności od sytuacji biograficznej danego aktora. Pracę nad tymi mechanizmami podejmuje także Daniel Cefaï (1994), wskazując, że

synteza identyfikacji i rozpoznania obejmuje przemieszczenie w czasie konfiguracji zjawisk, co prowadzi do konstruowania innych konfiguracji danego zjawiska napotkanych w przeszłości. Apercepcja ta dokonuje się poprzez 'obudzenie' lub przypomnienie nagromadzonych doświadczeń w syntezach przystawalności i pokrywania się - zwanych syntezami asocjacji, złączenia, dostosowania czy też aprezentacją (tamże: 109). pisze, że

Erving Goffman ([1974]1991) w pracach na temat 'ram doświadczenia' definicję sytuacji konstruuje się zwykle zgodnie z zasadami organizacji, które strukturyzują wydarzenia - przynajmniej te o charakterze społecznym - a nasze własne zaangażowanie pozostaje czysto subiektywne. Termin 'rama' określa te podstawowe elementy. Wyrażenie 'analiza ramowa' jest, z tego punktu widzenia, propozycją zachęcającą do badania organizacji doświadczenia (tamże: 19) ${ }^{37}$.

\footnotetext{
${ }^{36}$ Por. m.in.: Schütz (2008: 26-27).

37 Por. także: Goffman (2008).
} 
Zagadnienie tych związków podejmują także prace z zakresu psychologii ergonomicznej czy analizy aktywności (np. Roscha 1999; Theureau 1992; Duranda 2006; Zeitlera 2011) na temat procesów konstrukcji-rekonstrukcji typów, jak: pojawianie/emergencja, wzmocnienie czy osłabienie, uogólnienie przypadku, abdukcja, indukcja, dedukcja etc. Dla Molesa (1967) „Kultura indywidualna jest mentalnym ekranem poznania, na który jednostka rzutuje stimulusy - impulsy, jakie odbiera ze świata zewnętrznego, konstruując $\mathrm{w}$ procesie percepcji formy bardziej przystępne, przedstawiane symbolicznie w postaci słów lub znaków" (tamże: 68).

Związki te i powiązania wpływają na konstrukcje sensu tworzonych wokół samych aktywności ich otoczenia, jak również i podmiotów je podejmujących. Objawia się to szczególnie dużą spójnością między sposobami postrzegania, tworzenia koncepcji i działania w danej sytuacji, a także we wzajemnym pojawianiu się i transformacji konstrukcji odnoszących się do sytuacji (setting, afordancji), intencjonalności prowadzenia działania oraz konstrukcji reprezentacji tożsamościowych (subiektywności, intersubiektywności). Ta przystawalność i wzajemność ujmowana jest w kategoriach sposobów podzielania i kultury działania.

Te powiązania są 'wytwarzane' przez podmioty przy okazji różnego rodzaju 'doświadczeń', 'czynienia', a więc zaangażowania we wcześniejsze aktywności w tym samym polu, odczuwane jako 'doświadczenia', przy okazji których podmiot wysunął hipotezę takich związków czy asocjacji, a które później potwierdziły się; w tymże znaczeniu Michel de Certeau ([1990] 2004) mówi, że „kultura wytwarza się na co dzień w aktywnościach banalnych i powtarzanych, każdego dnia" (tamże: $13-30)^{38}$.

Doświadczenia 'komunikacji przy okazji czynienia': komunikacja między podmiotami zachodząca przy okazji aktywności, na drodze dyskursywnej czy innej, jest nośnikiem takich właśnie związków czy asocjacji. Język odgrywa tu bardzo ważną rolę i często przybiera funkcję nadawania jej znaczenia. Dlatego też M. de Certeau ([1990] 2004) mówi:

jesteśmy podporządkowani, choć niezidentyfikowanemu, zwyczajnemu językowi. Jak na statku szaleńców jesteśmy na pokładzie bez możliwości przeżycia dokonania bilansu. To 'proza życia', o której mówił Merleau-Ponty. Obejmuje ona cały dyskurs nawet, jeśli doświadczeń ludzi nie można zredukować do tego, co może ona o nich powiedzieć (tamże: 26).

\section{Dla A. Schütza ([1932]1974)}

Język jest systemem schematów typizacji doświadczenia, które opierają się na idealizacjach i anonimizacji bezpośredniego, subiektywnego do-

38 Por. także: Certeau (2008). 
świadczenia. Te typizacje doświadczenia oderwane od subiektywności są społecznie zobiektywizowane, przez co stają się składową społecznego a priori, uprzednio przekazanego podmiotowi. Dla jednostki dorastającej w naturalnych, oczywistych, sposobach postępowania, typizacja jest silnie powiązana z językiem (tamże: 282) ${ }^{39}$.

Doświadczenia specyficznej komunikacji na temat tych asocjacji i typów, co zresztą stanowi podstawową funkcję przypisaną nauczaniu, polegającą na sformalizowanej transmisji wypowiedzi odnoszących się do części tej kultury, tak omawia Pierre Bourdieu (1967):

w społeczeństwie, w którym transmisja kultury jest zmonopolizowana przez szkołę, głębokie podobieństwa łączą wytwory kultury (i oczywiście postępowanie oraz myślenie) z instytucją szkoły. Realizuje ona funkcję przekazu świadomego, ale także częściowo nieświadomego tego, co nieuświadamiane. Precyzyjniej mówiąc, szkoła produkuje jednostki wyposażone w system schematów nieświadomych (lub głęboko ukrytych), które stanowią ich kulturę lub raczej habitus (...) (tamże: 147-148).

W końcu, będą to doświadczenia działania, których wyraźną intencją jest 'rozwijanie' tych związków i asocjacji dokonywane poprzez refleksję, badanie, doświadczenia duchowe etc.

\section{Procesy interioryzacji i transformacji związków i powiązań konstrukcji sensu}

Te związki i powiązania są przedmiotem następujących stopniowo procesów interioryzacji, inkorporacji, co nie wyklucza ich transformacji. Mechanizm interioryzacji zachodzi oczywiście w uczeniu się ${ }^{40}$ oraz ogólnie kształtowaniu się podmiotów. Jednakże w tym przypadku dotyczy on szczególnie związków i asocjacji odnoszących się do rejestru mentalnego, co wzmacnia ich ujawnianie określonej sytuacji. Mechanizm ten może tłumaczyć „zapominanie” tych związków czy wyparcie w sferę nieświadomości. Opisuje go też inny konstrukt, jakim jest etos, definiowany przez Michela de Costera i François Pichaulta (1998), jako „zbiór znaczeń zinterioryzowanych przez aktora” (tamże: 68). Mechanizm interioryzacji jest szczególnie obecny w procesie percepcji, a zwłaszcza w tym, co nazywa się percepcją bezpośrednią. Alain Berthoz (1997) pojmuje percepcję jako „symulację działania” (tamże: 15-30). Podstawowe znaczenie ma tu pamięć, a w szczególności pamięć aktywności.

\footnotetext{
${ }^{39}$ Por. Schütz (2008: 156 i n.).

${ }^{40}$ Według Deweya uczymy się jedynie tego, co obecne jest w działaniu.
} 


\section{Formy kultur działania profesjonalnego: kultury działania naukowego}

Bardzo interesującym przykładem studiów nad kulturami działania, który znajduje się w kręgu zainteresowania wielu autorów, a zwłaszcza Michela Foucaulta i Thomasa Kuhna, są te aktywności, których specyficzną intencją jest tworzenie i komunikowanie wiedzy. Można w nich dostrzec wiele sposobów konstruowania sensu. Na temat kultur działania naukowego możemy poczynić trzy obserwacje.

Po pierwsze, pojawienie się aktywności naukowej, jako specyficznego działania, wydaje się następować na podstawie stopniowego pojawienia się idei względnej autonomizacji aktu poznania i równoległego nabierania dystansu, 'obiektywizacji' do świata, jako przedmiotu poznania. Ten sposób myślenia o procesie poznania wpisuje się w nowy sposób myślenia o działaniu człowieka. Jego cechą jest odróżnianie podmiotu od świata, na który człowiek oddziałuje, podmiotu działającego i przedmiotu oddziaływania, inaczej mówiąc: podmiotu od przedmiotu.

Słusznie czy też nie, wielu naukowców sytuuje pojawienie się nowej aktywności - 'nauki' (oraz 'naukowca') - na Zachodzie, na przełomie XV/XVI w., wraz z takimi myślicielami, jak: Kopernik (zdecydowanie porzucającym hipotezę humano-centryczną), Galileusz, Giordano Bruno etc. oraz umieszcza jej rozwój, począwszy od XVII w. Stopniowo wydaje się ona zakorzeniać jako dziedzina specyficznej aktywności, dystansująca się do świata, która może 'ukazać' pewien porządek pod postacią 'praw'. Jeśli przyjąć hipotezę E. Panofskiego, to, co charakteryzuje wiek poprzedni, tj. średniowiecze myśli scholastycznej i architekturę gotycką, to właśnie przeciwieństwo jedności aktywności ludzkiej, a szczególnie jedności rozumu i wiary: „Święta doktryna, jak mówił Tomasz z Akwinu, służy także rozumowi ludzkiemu nie po to, by udowadniać wiarę, lecz aby ukazać jasno (manifestare) to, o czym mówi ta doktryna" 41.

W pracach nad 'epoką klasyczną' Foucault ([1966] 2004) formułuje podobne stanowisko, mówiąc, że

system znaków w świecie zachodnim był od czasów stoicyzmu systemem trójkowym, wyróżniano w nim bowiem to, co znaczące (signifiant), to, co znaczone (signifie), i „koniunkturę” (tugchanon). Począwszy od XVII w., układ znaków będzie z kolei układem binarnym, bo w czasach Port-Royal zdefiniowany zostanie przez związek elementu znaczącego $\mathrm{z}$ elementem znaczonym. (...) Rozpada się w proch głęboka współzależność języka i świata. (...). Rzeczy i słowa zaraz wezmą rozwód. (...). Zadaniem dyskursu ma być mówienie o tym, co jest, choć on sam nie będzie niczym ponad to, co mówi. Olbrzymia reorganizacja kultury (...) (tamże: 57-58) ${ }^{42}$.

\footnotetext{
${ }^{41}$ St. Th. I qu. 1 , art. 8, ad 2.

${ }^{42}$ Cyt. za: Foucault (2006: 70-71).
} 
„To, co umożliwia całościowość épistémè klasycznej - jak dodaje - to przede wszystkim stosunek do poznania ładu” (tamże: 86), który „objawia się jako wewnętrzne prawo rzeczy, sekretna kratownica, w której rzeczy stoją obok siebie - choć zaistniał jedynie dzięki siatkom spojrzenia, uwagi i języka" (tamże: 11$)^{43}$.

To stanowisko podziela także François Jullien ([2000] 2005), mówiąc o relacji między sztuką a nauką w ten sposób: „jeśli nagość ${ }^{44}$ powraca z taką siłą w Renesansie i trwa całą epokę klasyczną (...), to dlatego, że jest współczesne obiektywnej nauce o naturze, opartej na wymogu uniwersalizmu praw (...)" (tamże: 60).

Po drugie, późniejsze strukturujące ukonstytuowanie się dyscyplin naukowych i odpowiadających im 'wspólnot' wydaje się mieć związek ze stopniowym pojawianiem się w umysłach jednostek nowego sposobu zarządzania, poprzez specjalizację, działaniami produkcji i komunikacji wiedzy. Sposób ten wpisuje się w nowe wyobrażenie organizacji aktywności ludzkich łączących specjalizację aktywności z wydajnościq czy postępem, co dobrze widać na przykładzie rozwoju podziału pracy $w$ dziedzinie ekonomii i produkcji dóbr.

Studia nad dyskursem dyscyplin lub dyskursem odniesień dyscyplinarnych umożliwiają uwypuklenie specyficznych cech poszczególnych kultur działania i wskazanie na następujące kombinacje reprezentacji zachodzących pomiędzy:

- określonym przedmiotem a odpowiadającym mu 'faktom', którymi w naukach społecznych będą 'fakty społeczne', 'zachowania' indywidualne, 'dyskursy' etc., w odniesieniu do których wysunięto hipotezę, przynajmniej prowizoryczną, że mogą stanowić odrębne przedmioty myślenia;

- określoną 'postacią aktora', kiedy 'uczonego' zastępuje 'fizyk', 'chemik', 'biolog', 'socjolog', 'psycholog' czy 'językoznawca';

- regułami wytwarzania rezultatów lub specyficznymi metodami kontrolowanymi przez wyspecjalizowane 'społeczności' zawodowe, formułowanymi w sposób wyraźny, lecz często zawartymi implicite, u ich podstaw (Cru 1986: 41). Według M. Foucaulta (1971) „Dyscyplina jest zasadą kontroli wytwarzania dyskursu. Ustala jego granice poprzez grę tożsamości, która ma formę permanentnej reaktualizacji reguł (tamże: 37 )" 45 ;

- sposobami interpretacji uzyskanych rezultatów.

Po trzecie, obecny w obrębie samych dyscyplin, i transwersalnie do nich, rozwój stanowisk epistemologicznych, oddziałując na koncepcję i prowadzenie działania, wydaje się także pozostawać w relacji z szerszymi sposobami myślenia i kierowania zwiq̨zkami pomiędzy tworzeniem wiedzy a transformacją świata. Znamienne jest na przykład ogromne podobieństwo, jakie można zaobserwować między postawami epistemologicznymi w dziedzinach nauk ścisłych i społecznych. A więc na przykład podobieństwo między mechaniką kwantową, teorią chaosu czy dyna-

\footnotetext{
${ }^{43}$ Cyt. za: tamże: 14.

44 To znaczy 'zobiektywizowane' ciało.

45 Cyt. za: Foucault (2002: 26) https://repozytorium.umk.pl/bitstream/handle/item/.../DP.2004. 013,Dominiak.pdf?...1 [dostęp: 1.12.2016].
} 
miką systemów a szkołami nauk społecznych, odwołującymi się w określaniu przedmiotu badań w ujęciu konstruktywizmu, podejścia klinicznego czy działania usytuowanego, jak również do rewizji pojęcia interakcji ${ }^{46}$, czy też do usytuowania przedmiotu badań w kontekście historycznym. Innym przykładem tych związków może być podobieństwo $\mathrm{w}$ zmianach modeli wnioskowania przyczynowego w odniesieniu do tzw. procesów „nieodwracalnych” (Prigogine 1993) czy też do szczególnego waloryzowania procesu konstruowania, czy kwestii tego, co potencjalne, możliwe, niestabilne bądź prawdopodobne. Podobne typy konceptów występują zarówno w naukach ścisłych, jak i naukach społecznych, np.: „trajektoria”, „czynniki ewolucji”, „uwrażliwienie na warunki początkowe” etc. W wielu przypadkach te orientacje epistemologiczne okazują się być związane dość bezpośrednio z różnymi sposobami 'sytuowania' działania naukowego poprzez wskazywanie na ich stosunek do okoliczności transformacji świata.

Począwszy od Kuhna ([1962] 1991), pojęcie paradygmatu stosowane jest do określania sposobów konstruowania sensu w danym polu. Paradygmaty sq $w$ rzeczywistości kulturami działania naukowego. Dla Isabelli Stengers ([1993] 1995)

Paradygmat stanowi przede wszystkim pewne uporządkowanie praktyczne. Obejmuje on nie tyle wizję świata, lecz raczej sposób działania, nie tyle formę osądu zjawisk, lecz raczej sposób oddziaływania (...). Właśnie dlatego, że paradygmat musi posiadać praktyczną moc odkrywania, operacjonalizowania faktów, których sam nie odkrywa, przynajmniej nie w tym samym sensie. Odkrywanie faktów jest kompetentne, poddające się dyskusji, sprytne, podczas gdy 'wymyślanie' paradygmatu według Kuhna narzuca się w sposób podobny do wydarzenia, które tworzy to, co przed nim i co po nim (tamże: $60-62)^{47}$.

W dobie obecnej termin ten znajduje nowe rozszerzenie wykraczające poza pole naukowe.

\section{Formy kultur działania profesjonalnego: kultury działania edukacyjnego}

Zarówno własne prace, jak i prowadzone w zespole pozwoliły nam na sformułowanie przypuszczenia o tym, że współcześnie możliwe jest wyodrębnienie różnych kultur działania edukacyjnego, czerpiących z różnych źródeł historycznych i społecznych. Działaniami edukacyjnymi nazywać będziemy takie działania, których intencją jest wywołanie lub wspieranie u innych podmiotów procesu

\footnotetext{
46 Pojęcie interakcji może być stosowane dla określenia stosunków między bytami świata, które jednocześnie biorą udział w procesie jego transformacji.

47 Por. Prigogine, Stengers (1990).
} 
uczenia się, to znaczy tak zorientowanej waloryzowanej dodatnio stałej organizacji aktywności lub transformacji sekwencji tego procesu. Ta intencjonalność wydaje się przebiegać trzema drogami, każda z nich posiada wcześniej już wyodrębnione cechy kultur działania. Są to: kultury nauczania, kształcenia/kształtowania/formowania, towarzyszenia. Zawierają one w szczególności tworzenie odmiennych reprezentacji oraz dyskursów odnoszących się do: relacji między przedmiotem i podmiotem działania edukacyjnego, specyfiki aktorów, „czasoprzestrzeni” i jej stosunku do otoczenia oraz przekształceń.

\section{Kultury nauczania}

Specyfiką kultur nauczania jest pojmowanie działania edukacyjnego jako aktywności podmiotów 'nauczających' oddanej do dyspozycji wiedzy, wzmacnianej przez podmioty 'nauczane' aktywnościq 'przyswajania'.

Kategorie przedmiotu/podmiotu działania edukacyjnego są pojmowane w odniesieniu do terminów 'wiedza ogólna' i 'indywidualna wiedza podmiotu/wiedza własna'. Terminem wiedzy ogólnej określa się wypowiedzi pisemne lub ustne istniejące niezależnie od osób ją wypowiadających lub ją sobie przypisujących, a zatem ta wiedza jest jak gdyby 'oddana do dyspozycji' podmiotów. Indywidualna wiedza podmiotu/wiedza własna stanowi spodziewane dopełnienie wiedzy ogólnej, wytworzone przez podmioty nauczane. Są to dwa stany indywidualny i zbiorowy, jakich spodziewamy się jako efektu interioryzacji wiedzy. Kultury nauczania charakteryzują następujące cechy:

- aktorów tego oddziaływania określa się terminem nauczyciel, posiadający i przekazujący wiedzę, oraz uczeń lub student, adresat i potencjalny 'nabywca';

- czasoprzestrzeń oddziaływania edukacyjnego pojmowana jest jako oddana do dyspozycji wiedzy w przyswajalnej formie;

- stosunki między tak rozumianą przestrzenią a otoczeniem są określane terminem konceptualizacji/aplikacji (teorii/praktyki);

- czynnikiem uruchamiającym zmianę jest pojawienie się nowej wiedzy/nowych stanowisk.

Funkcjonowanie kultur nauczania wydaje się być spójne z ogólnie pojmowanymi kulturami działania, w których wyróżnia się i hierarchizuje słowa, myśli i działanie, hierarchia ta jest bardzo ustrukturyzowana w myśli zachodniej, odnajdujemy ja w wyróżnieniach - opozycjach - dopełnieniach odnoszących się do takich kategorii, jak: teoria/praktyka, koncepcja/realizacja, akademickość/profesjonalność. Kultury te odwołują się także do sposobów organizacji pracy i aktywności opartych na społecznym zróżnicowaniu prowadzenia i wykonywania działania. Wiedza ogólna oraz indywidualna wiedza podmiotu/wiedza własna stanowią część sfery 
semantycznej wypowiedzi odnoszących się do wartości, reguł i norm, a ogólniej wypowiedzi będących podstawą waloryzacji społecznej wyrażanej w postaci aktywności: transmisja-komunikacja (kultura sformalizowana).

\section{Kultury kształcenia}

Ich cechq wyróżniającq jest ujmowanie działania edukacyjnego, jako działania wyraźnie powiązanego, połączonego, łączącego aktywności i podmioty 'formujące' z aktywnościami podmiotów 'uczących się' w celu wytworzenia u uczących się nowych umiejętności/potencjałów transferowalnych, możliwych do przeniesienia na inne sytuacje. Oznacza to, że: relacja przedmiot-podmiot działania edukacyjnego jest pojęciem określającym możliwości, definiowanym raczej w kategorii bycia niż posiadania, jako zdolny do zmian konstrukt indywidualny, którego nośnikiem jest podmiot uczący się. Funkcjonuje jako potencjał odpowiadający pewnej klasie aktywności;

- aktorzy są formatorami/kształcącymi, organizatorami sytuacji uczenia, a uczący się podmiotem swojego 'własnego' uczenia się;

- czasoprzestrzeń oddziaływania na inne sytuacje ujmowana jest jako taka w procesie transformacji możliwości/potencjałów;

- stosunki/relacje między tą czasoprzestrzenią a otoczeniem są raczej ujmowane w kategoriach dekontekstualizacji - rekontekstualizacji;

- czynnikiem uruchumiającym zmianę jest pojawienie się nowych aktywności lub nowych pól aktywności, dla których muszą być wytworzone nowe umiejętności/kompetencje.

Kultury kształcenia wydają się być spójne ze sposobami myślenia o działaniu, wyodrębniając i łącząc aktywności zorganizowane wokół konstruowania podmiotów (kształtowanie, formowanie) z aktywnościami ukierunkowanymi na uaktywnianie podmiotów (produkcja), jak to jest w przypadku 'kształcenia naprzemiennego' czy 'kształcenia przez całe życie'. Kultury kształcenia, zachowując względną autonomię, odwołują się do sposobów organizacji pracy, opartych na waloryzacji zarządzania działaniem, na różnicowaniu 'pól działania' oraz na powiązaniach między nimi. W sferze semantycznej kategoria potencjału zbliżona są bardziej do walorów, zręczności, zdolności powstających w wyniku konstrukcji-rekonstrukcji stosunku podmiotów do ich własnych aktywności, względnie oddzielonych od ich zaangażowania afektywnego w te aktywności in situ.

\section{Kultury towarzyszenia}

Kultury towarzyszenia charakteryzuje pojmowanie działania edukacyjnego jako pewnej uzupełniającej aktywności społecznej realizowanej obok podstawowej aktywności podmiotu, któremu się towarzyszy, w celu równoczesnej optymalizacji 
aktywności, w którq jest on zaangażowany oraz jego własnej transformacji jako podmiotu. Mówi się czasem o 'kształceniu zintegrowanym z działaniem', a kiedy aktywności podstawowe podmiotu są podejmowane $\mathrm{w}$ obszarze pracy czy produkcji, mówimy wówczas o 'kształceniu zintegrowanym z pracą lub produkcją'. To, co określa się jako przedmiot czy podmiot oddziaływania edukacyjnego jest dziś często sytuowane w terminologii z zakresu kompetencji. Kompetencje są konstruktami, o obecności których można wnioskować na podstawie zaangażowania podmiotów w działania usytuowane i finalizowane, zawierające sens nadawany tym aktywnościom przez podmioty oraz znaczenia, jakie im przypisują.

Kultury towarzyszenia charakteryzuje to, że:

- aktorami są: sam 'praktyk' i także akompaniator jego rozwoju/osoba towarzysząca jego rozwojowi;

- kategorie przestrzeni i czasu obecne w procesach transformacji świata oraz transformacji podmiotów nie są oddzielone: tworzenie dóbr i usług czy 'zwykła' aktywność zorganizowane są podobnie jak przestrzeń 'rozwoju kompetencji' indywidualnych, czy ich 'wzrostu';

- stosunki między przestrzenią rozwoju kompetencji a ich wzrostem i otoczeniem charakteryzują transformacje powiq̨zane;

- czynnikiem uruchamiającym zmianę są nowe kombinacje aktywności, które wcześniej były oddzielone (chodzi tu np. o wspólne projekty integrujące czy wskazówki typu 'polichromii').

Kultury towarzyszenia są spójne w swoim funkcjonowaniu z bardziej ogólnymi sposobami myślenia o działaniu, w których nie oddziela aktywności transformacji świata i równolegle zachodzącej transformacji siebie. Przykładem takiego sposobu myślenia o działaniu mogą być podejścia inspirowane konstruktywizmem, które wpisują się w aktualnie podzielane modele pracy i produkcji typu 'pull', odpowiadające ekonomii 'usług'. Pokrywają się z rejestrami znaczeniowymi skupionymi na określaniu podmiotów ludzkich $w$ odniesieniu do ich zaangażowania $w$ działanie, szczególnie terminu 'podmiot' w znaczeniu społecznym, określającym podmiot z punktu widzenia jego działania.

Obserwacja ta prowadzi do konstatacji pewnego braku zrozumienia w obrębie tych trzech kultur, omawianych powyżej, jak również pewnych stosunków władzy między nimi, co potwierdzałoby specyfikę tych kultur działania. Jednocześnie mamy do czynienia z niezaprzeczalnym naciskiem społecznym wywieranym w celu tworzenia ich kombinacji w ramach szerszych dyspozytywów edukacyjnych. Takie połączenie okazuje się często sztuczne i trudne do stworzenia, co tym bardziej wykazuje przydatność zabiegu pojmowalności tych kultur. Przypuszczalnie kultury te nie dążą do eliminacji, lecz do rekonfiguracji zajmowanego miejsca w 'konstrukcjach' bezustannie ewoluujących (tak jak zresztą kultury produkcji). 


\section{Konkluzja: nasze konstrukcje sensu, tak obce, gdyż tak bliskie}

Zaproponowane podejście do kultur działania jawi się jako projekt natury antropologicznej, jednakże odnaleźć w nim można bardzo ważne elementy filozoficzne i semantyczne. Oznacza to z pewnością konieczność ponownego zadania pytania o stosunek między subiektywnością a postępowaniem naukowym. Podejście to pociąga za sobą zamierzenie o wiele szersze i trudniejsze, wymagające opracowania problematyki przebiegu procesu konstruowania sensu przez podmiot w kilku płaszczyznach: epistemologicznej, teoretycznej i metodologicznej. Zagadnienie konstruowania sensu jest prawdopodobnie mniej znane podmiotowi, z tego powodu, że wydaje mu się zbyt znane, bo bliskie.

\section{Bibliografia}

Anscombre J. C. (red.) (1995) Théorie des topoï, Paris, Kime.

Barbier J. M. (2000a) La singularité des actions : quelques outils d'analyse w: J. M. Barbier, 0. Galatanu (dir.), L'analyse de la singularité de l'action, Paris, Presses Universitaire de France : $13-51$.

Barbier J. M. (2000b) Sémantique de l'action et sémantique d'intelligibilité des actions w: Maggi B. Manières de penser, manières d'agir en éducation et formation, Paris, Presses Universitaire de France.

Barbier J. M. (2006) Działanie w kształceniu i pracy socjalnej. Analiza podejść, tłum. G. Karbowska, Katowice, Wydawnictwo Naukowe „Śląsk”, Seria Biblioteka Pracownika Socjalnego.

Barbier J. M. (2016) Leksykon analizy aktywności. Konceptualizacja zwyczajowych pojęć, przekł. oprac. E. Marynowicz-Hetka, Łódź, Wydawnictwo Uniwersytetu Łódzkiego.

Barnes B. ([1990] 1998), Thomas Kuhn, w: Powrót wielkiej teorii, Q. Skinner (red.), przekł. T. Łozowski, Lublin, Wydawnictwo Uniwersytetu Marii Curie-Skłodowskiej, s. 99-118.

Berthoz A. (1997) Le sens du mouvement, Paris, O. Jacob.

Boas F. (1898) Introduction to: James Teit, Traditions of the Thomson River Indians of British Columbia, „Memoirs of the American Folklore Society”, vol. 6.

Bourdieu P. (1967) Postface à : Panofsky E. Architecture gothique et pensée scolastique Paris, Minuit : 135-167. 
Bruner J. (1996) L'éducation, entrée dans la culture. les problèmes de l'école à la lumière de la psychologie culturelle, Paris, Retz.

Bruner J. (2006) Kultura edukacji, tłum. T. Brzostowska-Tereszkiewicz, Kraków, Universitas.

Cefaï D. (1994) Type, typicalité, typification. La perspective phénoménologique w: B. Fradin, L. Quere, J. Widmer, L'enquête sur les catégories. raisons pratiques, 5 Paris, Ehess : 105-128.

Certeau M. de ([1990] 2004) L'invention du quotidien. L'art de faire, Paris, Flammarion.

Certeau M. de (2008), Wynaleźć codzienność. Sztuki działania, tłum. K. Thiel-Jańczuk, Kraków, Wydawnictwo Uniwersytetu Jagiellońskiego.

Cru D. (1986) Collectif et travail de métier; sur la notion de collectif de travail, in plaisir et souffrance au travail, (sous la dir.) de C. Dejours, Paris, Edition de L'AOCIP/CNRS, 1988-1993, t. $1: 40-46$.

Coster de M., Pichault F. (red.) (1998 2ème) Traité de sociologie du travail, Préface d'A. Touraine, Louvain-la-Neuve, de Boeck Université.

Cuche D. ([1996] 1998) La notion de culture dans les sciences sociales, Paris, La découverte.

Dewey J. ([1938] 1993) La théorie de l'enquête, Paris, Presses Universitaire de France.

Duchamp M. (1975) Duchamp du signe, Paris, Flammarion.

Ducrot 0. (1989) Zarys polifonicznej teorii wypowiadania się, tłum. A. Dutka, „Pamiętnik Literacki”, LXXX, z. 3, s. 257-303, bazhum.muzhp,pl [dostęp: 14.11.2016].

Durand M. (2006) Apprentissage et configuration d'activité: une dynamique ouverte des rapports sujets-environnements w: J. M. Barbier, M. Durand, Sujets/activités/ environnements - approches transverses, Paris, Presses Universitaire de France: 61-84.

Foucault M. ([1966] 2004) Les mots et les choses, Paris, Gallimard.

Foucault M. (1968) Dits et écrits, t. 1, Paris, Gallimard.

Foucault M. ([1969] 2004) L'archéologie du savoir, Paris, Gallimard.

Foucault M. (1971) L'ordre du discours, Paris, Gallimard. 
Foucault M. (1977) Archeologia wiedzy, tłum. Andrzej Siemek, Warszawa, PIW.

Foucault M. (2002) Porządek dyskursu. Wykład inauguracyjny w Collège de France, 2 grudnia 1970, tłum. M. Kozłowski, Gdańsk, Wydawnictwo Słowo/obraz terytoria.

Foucault M. (2006) Słowa i rzeczy. Archeologia nauk humanistycznych, tłum. T. Komendant, Gdańsk, Wydawnictwo Słowo/obraz terytoria.

Galatanu 0. (1999) Le phénomène sémantico-discursif de déconstruction-reconstruction des topoï dans une sémantique argumentative intégrée, „Langue Française”, nr 123, sept. Larousse.

Goffman E. (1974/1991) Les cadres de l'expérience, Paris, Minuit.

Goffman E. (2008) Analiza ramowa. Esej z organizacji doświadczenia, tłum. S. Burdziej, wstęp M. Czyżewski, Kraków, Zakład Wydawniczy „NOMOS”.

Herskovits M. J. ([1948] 1952) Les bases de l'anthropologie culturelle, Paris, Payot.

Hofstadter D. ([1979] 1987) Gödel, Escher, Bach : les brins d'une guirlande éternelle, Paris, Intereditions.

Jullien F. ([1992] 2003) La propension des choses. Pour une histoire de l'efficacité en chine, Paris, Seuil.

Jullien F. ([2000] 2005) Le Nu impossible, Paris, Seuil.

Jullien F. (2006) Drogq okrężnq i wprost do celu. Strategie sensu w Chinach i Grecji, tłum. M. Falski, Kraków, Wydawnictwo Uniwersytetu Jagiellońskiego.

Kuhn T. ([1962] 1991) La structure des révolutions scientifiques, Paris, Flammarion.

Lévi-Strauss C. (1962) La pensée sauvage, Paris, Plon.

Lévi-Strauss C. (1969) Myśl nieoswojona, tłum. A. Zajączkowski, Warszawa, PWN, Seria Biblioteka Socjologiczna.

Lévi-Strauss C. (1970) Antropologia strukturalna, tłum. K. Pomian, Warszawa, PIW.

Levy-Bruhl L. (1910) Les fonctions mentales dans les sociétés inférieures, Paris, Presses Universitaire de France.

Levy-Bruhl L. ([1918] 1992) Czynności umysłowe w społeczeństwach pierwotnych, tłum. B. Szwarcmann-Czarnota, Warszawa, PWN, Biblioteka Klasyków Psychologii. 
Levy-Bruhl L. ([1922] 1960) La mentalité primitive, Paris, Alcan.

Linton R. (1988) Le fondement culturel de la personnalité, Paris, Dunod.

Linton R. (2000), Kulturowe podstawy osobowości, tłum. A. Jasińska-Kania, Warszawa, Wydawnictwo Naukowe PWN, http://www.khg.uni.wroc.pl/files/9_khg_13_pilarska_ t.pdf [dostęp: 1.09.2016].

Malinowsky B. ([1944] 1970) Une théorie scientifique de la culture, Paris, François Maspero.

Malinowski B. ([1944] 1958) Naukowa teoria kultury, tłum. H. Buczyńska w: B. Malinowski, Szkice z teorii kultury, Warszawa, Książka i Wiedza, s. 3-111.

Moles A. (1967) Sociodynamique de la culture, Paris, Mouton.

Moles A. (1978) Kicz, czyli sztuka szczęścia. Studium o psychologii kiczu, tłum. A. Szczepańska, A. Wende, Warszawa, PIW.

Morin E. (2001) Le monde comme notion sociologique in. D. Mercure (dir.), Une société-monde? Les dynamiques sociales de la mondialisation, Presses de l'Université Laval, De Boeck.

Panofsky E. ([1951] 1967) Architecture gothique et pensée scolastique, Paris, Minuit.

Polin R. (1977) La création des valeurs, Paris, Vrin, 3ème édition, manuscrit 1943.

Prigogine I. ([1993] 1997) Les lois du chaos, Paris, Flammarion.

Prigogine I., Stengers I. (1990) Z chaosu ku porządkowi. Nowy dialog człowieka z przyrodą, tłum. K. Lipszyc, PIW, Biblioteka Myśli Wspołczesnej.

Quere L. (1990) Agir dans l'espace public raisons pratiques. Les formes de l'action, Paris, Editions de l' ehess.

Rosch E. A. (1999) Reclaiming concepts, „Journal of Consciouness Studies”, 6 (11-12), s. 61-77.

Schütz A. ([1932] 1974) Der sinnhafte aufbau der sozialen welt, Francfurt am Main, Suhrkamp 'Taschenbuch Wissenschaft'.

Schütz A. (2008) O wielości światów. Szkice z socjologii fenomenologicznej, tłum. B. Jabłońska, A. Manterys (red. nauk.), Kraków, Zakład Wydawniczy „NOMOS”.

Stengers I. ([1993] 1995) L'invention des sciences modernes, Paris, Flammarion. 
Szacki J. (2002) Historia myśli socjologicznej. Wydanie nowe, Warszawa, Wydawnictwo Naukowe PWN.

Theureau J. (1992) Le cours d'action, Berne, Peter Lang.

Thevenet M. (1983) L'audit de la culture d'entreprise, Paris, Editions d'organisation.

Tylor E. B. (1871) Primitive culture, London, J. Murray.

Weber M. ([1904-1905] 1964) L'éthique protestante et l'esprit du capitalisme, Paris, Plon.

Wittgenstein L. (1922/2001) Tractatus logico-philosophicus, Paris, Gallimard.

Wittgenstein L. (2000), Tractatus logico-philosophicus (Traktat logiczno-filozoficzny), tłum. i wstęp B. Wolniewicz, Warszawa, Wydawnictwo Naukowe PWN, Biblioteka Klasyków Filozofii.

Zeitler A. (2011) Les apprentissages interprétatifs, Paris, l'Harmattan, Action et Savoir.

Tłumaczenie z języka francuskiego: Grażyna Karbowska

Konsultacja naukowa: Ewa Marynowicz-Hetka

Jean-Marie Barbier

\section{Cultures of Action and Shared Ways of Organizing the Construction of Sense}

\section{Invariable elements in professional thinking}

The analysis of patterns of professional thinking and intellectual life, especially the so-called "social professions", in the areas of education, social, therapeutic, management or cultural activities, indicates the presence of unchanging elements in the discourse on the concept and conduct of professional activities and their management. These immutable elements can be found in the discourse and in the description of the activities, practices, presented models of action, transferring knowledge on the activity, promoting professional values, developing techniques and operating procedures. 
It can be assumed that the emergence and development of these cultures of professional action is related to 'mental habits' and 'folds of reason', which appear to be obvious patterns acquired and shared in given circumstances by a particular set of people. We can therefore talk more broadly about cultures of action, which we pre-define as forms/means of 'action-in-the-act', common to a certain group of people in thinking about acting, designing and conducting activity, and more generally in the construction of sense around them and assigning meaning to them. The term action does not mean here only (or at least not exclusively) the direct transformation of the world, but is used in a more general sense as all activities having the unity of sense and/or importance for the actor or actors involved in them in the context of interaction with other actors.

\section{Example: cultures of educational action}

Today, it is possible to isolate different cultures present in educational actions that draw on different historical and social sources. Educational actions are here such actions oriented on educational acts that are intended to induce or support the self-learning process in other actors. The selflearning process means the positively indexed permanent organization of activities or the transformation of the sequence of this process.

This intentionality seems to run along three ways, which include creating different representations and discourses relating to: the relationship between the subject and the object of educational action, the specificity of the actors, the "space-time" and its relation to the environment and the transformations.

\section{Cultures of teaching}

The specificity of cultures of teaching involves understanding the educational action as the activity of the subjects 'teaching' the knowledge that is made available, reinforced by the subjects 'taught' with the activity of 'assimilation'. The actions involved are defined by the following characteristics:

- categories of object/subject of educational action are conceived in relation to the terms 'general knowledge' and 'personal knowledge of the subject/self-possessed knowledge'. The term 'general knowledge' refers to the statements, written or oral, existing independently of the contributors or people ascribing them to themselves, and therefore this is knowledge as if 'placed at the disposal' of the subjects. Personal knowledge of the subject/self-possessed knowledge makes the anticipated complement to the general knowledge produced by the 
subjects that are taught. These are two states, individual and collective, which we expect as a result of interiorization of knowledge;

- actors of this interaction are referred to as a teacher, holding and transferring knowledge, and a student, i.e. a recipient and potential 'acquirer';

- the space-time of educational impact is understood as the knowledge placed at the disposal in the available form;

- the relationships between the space and the environment conceived in such a way are referred to as conceptualization/application (theory/ practice);

- the trigger for the change is the emergence of new knowledge/new positions.

\section{Cultures of formation}

Their distinguishing feature is the recognition of educational action as the activity clearly related, connected, linking the activities and 'training' subjects with activities of 'learners' in order to produce in learners new skills/potentials transferable to other situations. What is specific for the training cultures is that:

- the subject-object relationship of educational action is a concept defining the capabilities, recognized rather in the category of being than having, as an individual construct capable of change, the carrier of which is the learning subject. It functions as potential corresponding to a certain class of activity;

- the actors are formatters/trainers, animators of learning situations, and the learners are the subject of their own learning;

- the space-time of impact is understood as such in the process of transformation to other situations of opportunities/potentials of the individual;

- the relations/relationships between this space and the surroundings are rather perceived in terms of decontextualization-recontextualization;

- the trigger for the change is the emergence of new activities or new fields of activity, for which there must be generated new skills/ potentials.

\section{Cultures of supporting activities}

Cultures of accompaniment are characterized by comprehending educational action as certain complementary social activities pursued alongside the basic action of the subject, which is accompanied, in order to simultaneously optimize the activities in which he/she is involved and his/her own 
transformation as the subject. Sometimes we talk about 'education integrated with action', and when the basic activities of the subject are undertaken in the area of work or production, we talk about 'education integrated with work or production'. These cultures are characterized by several special features:

- what is defined as an object or subject of educational impact is today often situated within the terminology from the area of competences. Competences are constructs, the presence of which can be inferred from the involvement of the subjects in activities arranged and finalized, containing sense given to these activities by the actors and the importance they attribute to them;

- actors referred to in the discourse on the cultures of accompaniment are: the 'practitioner' himself/herself, and also the accompanier of his/her development/person accompanying the development;

- the categories of space and time present in the processes of the transformation of the world and the transformation of subjects are not separated: the creation of goods and services or 'normal' activities are organized similarly to the space of individual 'competences development', or their 'growth';

- relationships between the space of competences development and their growth and the environment are characterized by related transformations;

- the trigger inducing change are rather new combinations of activities that were previously separated (for instance, common integrating projects or indications similar to 'polychrome').

\section{Cultures of action and their characteristics}

A culture of action is defined as the evolving and shared by many actors manner of organization of construction of sense around the activity in which they are involved; these constructions can foster communication within the framework of interactions with the other.

\section{Manner of organization}

The manner of organization can be defined as an inference on the basis of the unchangeable or the regularity of the observable action-in-the-act in organizations. Similarly to all concepts of cognition of products in social sciences, and more broadly in science, it is assumed in that inference that the concept of the culture of activity makes the construct that allows to give an account of what is observable. 
As regards the organization of action-in-the-act, Jullien speaks of 'folds' of reason (plis de raison), Panofsky about the 'mental habit', and the fact that it is about mental activity does not undermine the interest in modus operandi, as it does not engage the consciousness of the subject although, of course, it does not exclude it, either.

Mental habits are often unconscious, forgotten or hidden at the level of the individual subject or group of belonging (as in the case of forgetting about the origins of the structure of words/etymology). According to Jullien, cultures of action derive mainly from the 'not-conceived', with processes that are unconscious or hidden, and even more interesting when it comes to what we do not wonder about in the process of thinking (impensés de pensée).

\section{Shared by many}

Shared does not mean collective. Precision is extremely important in the present era, when the heads of social organisms exert strong pressure on their members so that they all construct the same sense or attribute the same meaning to collective activities, and to what each of them brings to the whole (especially through coordinative actions), and all this in order to form collective identity representations. The conducted research and observations allow to distinguish similar cultures of action of subjects that are widely dispersed despite belonging to the same human collective.

\section{Human subjects}

There is no culture with carriers other than human subjects. Therefore, it is important to distinguish, following the old nomenclature, the 'creations/ works' of human activity, which are considered to be the 'demonstrations/ manifestations' of culture (while they are only the inference produced based on them) and what we can conclude based on them about human beings, their creators, and what comes from the culture itself.

According to our assumption, relative ambiguity characteristic for the definition of cultures is linked to the fact that works are presumably the carrier of the 'trace' of cultures and their 'manifestations', which lets us understand the expanded range of the uses of this term. In fact, works allow us to conclude about the processes running in humans, but they cannot substitute them.

\section{Transgression of culture}

Stating that culture is inextricably linked with human subjects and their relationships with the environment inevitably leads to the question about its design and evolution. Cultures, even if they are probably temporary or more 
permanent stabilizations of this process, are the product of activities and contribute to their creation.

Even though the word "transmission" is not always appropriate, culture and teaching are closely related if we understand teaching as a transformation of a certain fixed sequence of activity.

Organization of construction of sense of activities in which (actors) are involved

This obviously regards the most important aspect of our definition. If sense can be defined as an association made by the subject, between the representations coming from current activity and other representations that emerged in the course of his/her way of life, then we see that human beings in the course of their activity constantly make this type of constructions, and these relate both to the environment of their activity, their organization and conduct, and to themselves, as actors, and other subjects with whom they interact. Jeremy Bruner (1996) in his conception of cultural psychology attributed the greatest importance to constructions of sense.

We formulate the assumption that cultures of action can be defined as means of organizing the activity of constructing sense. This property is particularly evident in the phenomenon of acculturation, which can be described as a process of re-interpretation.

Constructions of sense and the interaction between human subjects

These constructions can lead to communication within the framework of interactions with other actors or groups of actors. We formulate the hypothesis that the term "culture" in the most common social applications (e.g. in the field of culture) occurs in situations of interaction on the occasion of the act of revealing specific forms of communication with the other and different channels of expression, and in the process of construction of sense created by subjects or groups of subjects. At that time, there appear activities or sectors of activity having social importance and separate status. Traditionally, this embraces sectors of art, literature and science. In a more contemporary approach, also production, dissemination and consumption of products/creations of the mind are included.

Translation by Magdalena Machcińska-Szczepaniak 